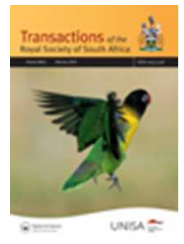

\title{
Late Quaternary research in southern Africa: progress, challenges and future trajectories
}

\begin{tabular}{|r|l|}
\hline Journal: & Transactions of the Royal Society of South Africa \\
\hline Manuscript ID & TTRS-2016-0031.R1 \\
\hline Manuscript Type: & Reviews \\
\hline Keywords: & $\begin{array}{l}\text { Southern Africa, palaeoenvironmental research, state of the science, } \\
\text { proxies, site selection }\end{array}$ \\
\hline \multicolumn{2}{|l}{} \\
\hline
\end{tabular}




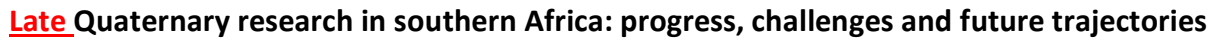

2

\section{Abstract}

4 Southern African late Quaternary research has developed rapidly during recent decades, with an increase in 5

\section{Keywords}

Southern Africa, palaeoenvironmental research, state of the science, proxies, site selection.

\section{INTRODUCTION}

Past environmental and climatic reconstructions using climate proxies isolated from sediment profiles were initiated comparatively late in southern Africa, compared to work elsewhere in the world (Scott, 1982a,b; Van Zinderen Bakker \& Coetzee, 1988). Pioneering studies by Van Zinderen Bakker (1955), Martin $(1959,1968)$, Coetzee (1967), Schalke (1973), and Scott $(1976,1982 a)$, were limited by uncertain chronologies, and by the considerably rich and varied flora of the region, for which no pollen collections existed (Scott, 1989; Van Zinderen Bakker \& Coetzee, 1988). In recent years, studies have benefitted from access to increasingly affordable high precision dating facilities, and large pollen, phytolith and diatom collections to facilitate the identification of proxies (Kristen et al., 2007; Meadows, 2014). Despite these advances, and given the geographical and botanical diversity of the region, considerable research gaps still exist and many localities 
within the region remain under-represented (Kristen et al., 2007; Neumann et al., 2008). This is partly due to

37 the scarcity of sites with uninterrupted, undisturbed sediment profiles that contain sufficient concentrations of fossil proxies to produce robust analyses, and a sparse distribution of caves with well-preserved speleothems 39 (Martin, 1968; Livingstone, 1975; Van Zinderen Bakker \& Coetzee, 1988; Kristen et al., 2007; Neumann et al., 2008). Unlike much of Europe, for which numerous palaeoecological studies have been undertaken due to the wealth of palaeoenvironmental archives, much of southern Africa is too arid to support the preservation of microfossils (including pollen and aquatic microfossil proxies such as diatoms, ostracods, and testate amoeba) (Livingstone, 1975; Scott, 1989; Chase \& Meadows, 2007; Fitchett et al., 2016). Consequently, research has largely been confined to wetlands in the more humid eastern region of southern Africa, and isolated springs in the interior (Scott, 1989; Neumann et al., 2008; Figure 1).

This paper presents a review of southern African palaeoenvironmental reconstructions published to date, critically exploring the spatial gaps in the literature. We identify three key debates around which considerable uncertainty exist: fluctuations in the latitudinal extent of the Westerlies, the correspondence with Northern Hemisphere late Quaternary environmental and climatic events, and the climatic conditions during the Last Glacial Maximum (LGM). This uncertainty is limiting the understanding of the nature of continental southern African environmental responses to global changes in climate. These debates are critically assessed through a spatial lens, from which recommendations for future site selection are made to facilitate research attempting deliberately to resolve these uncertainties. The current array of palaeoenvironmental proxies utilised in southern African late Quaternary science is critically assessed, with recommendations for their further use to more accurately resolve the aforementioned debates. This review then details future prospects in southern African palaeoenvironmental science, including the applications of this research in climate model validation, ecosystem management, and understanding fire dynamics, and reconstructing anthropogenic influence on the natural environment.

60 
63 Three climatic zones characterise the southern region of southern Africa: the winter rainfall zone (WRZ) confined to the southwestern Cape, the year-round rainfall zone (YRZ) spanning much of the southern coast of South Africa, and the summer rainfall zone which comprises the interior of South Africa, and Lesotho, Swaziland and the northern bordering countries (Engelbrecht et al., 2015; see Chase \& Meadows, 2007 for a map of spatial rainfall seasonality distribution). For the southern region of southern Africa, including southern Namibia, South Africa, Swaziland and Lesotho, the most important synoptic scale changes that have likely occurred during the late Quaternary are shifts in the position and strength of the westerly belt, with resultant influences on the position of the WRZ and associated spatial changes in biomes (Barrable et al., 1998; Chase \& Meadows, 2007; Stager et al., 2012; Bamford et al., 2016; Stowe \& Sealy, 2016; Fitchett \& Bamford, 2017). The WRZ is an important geographical region as one of few Southern Hemisphere examples of Mediterranean-type climates (Barrable et al., 1998). The region is characterised by high floristic diversity, and is the endemic habitat of the majority of the Fynbos group of species, a biome constrained by the position of the regular intrusion of mid-latitude cyclones in winter, and drier summer conditions (Barrable et al., 1998; Chase \& Meadows, 2007; Quick et al., 2015, 2016). The WRZ is thus climatically and ecologically distinct from the SRZ

77 (Stager et al., 2013), but is arguably distinct also from the YRZ, despite similarities in vegetation (Van Zinderen Bakker, 1976; Barrable et al., 1998; Carr et al., 2006; Chase \& Meadows, 2007; Engelbrecht et al., 2015; Quick et al., 2015). It is argued that during glacial periods, the reduced energy budget of the planet and associated increase equator-ward expansions in Antarctic sea ice would have resulted in a contraction of the tropical belt, northward-and equator-ward shifts in the Westerlies and an associated expansion of the southern African WRZ (Van Zinderen Bakker, 1976; Cockroft et al., 1987; Chase \& Meadows, 2007). There is concern that should the Westerlies retreat pole-wards under contemporary climate change, a greater incidence of drought in the WRZ may occur (Christensen et al., 2007; Engelbrecht et al., 2009; Stager et al., 2012). It is difficult to obtain direct or reliable information on the seasonality of past rainfall for a particular region from climate proxies, which instead reflect broader fluctuations in total annual precipitation (Chase et al., 2015a). There is thus on-going debate concerning the nature and extent of such geographic shifts in the position of Westerlies (Chase \& Meadows, 2007; Fitchett \& Bamford, 2017).

Late Quaternary shifts in the latitudinal position of the westerlies have been of palaeoenvironmental interest 91 for many decades, initiated by the work of Van Zinderen Bakker (1976) and Cockroft et al. (1987). Van 

Zinderen Bakker (1976) originally suggested an expansion of Mediterranean Cape flora and the associated WRZ as far north as $\sim 24^{\circ} \mathrm{S}$, encompassing Namibia and the Free State during the LGM. This was later revisited, and Van Zinderen Bakker (1983) conceded that whilst considerably stronger Westerlies occurred during the LGM, the westerly belt and associated vegetation probably did not extend as far north as originally proposed. More recently, studies within the southern Cape region have led to some consensus that the strength of the westerly belt and the resultant WRZ expanded in both northerly (Barrable et al., 1998; Chase \& Meadows, 2007; Stager et al., 2012) and easterly (Carr et al., 2006; Chase \& Meadows, 2007) directions, although the geographic limits of these shifts remain uncertain. Changes in the extent of the westerly belt also influence the frequency and intensity of mid-latitude cyclones which move into the interior regions of South Africa. Pollen, diatom and phytolith records from Braamhoek Wetland (Figure 1), located north of the WRZ in the Free State Province of South Africa, provide evidence for a greater influence of mid-latitude cyclones, associated with a northward shift of the westerly belt towards the South African interior during the terminal Pleistocene (Norstöm et al., 2009, 2014; Finné et al., 2010). This is in agreement with palaeogeomorphological evidence for eastern Lesotho, indicating an increased intensity of mid-latitude cyclones reaching the Lesotho highlands during the late Pleistocene (Mills et al., 2012). Recently, palaeoenvironmental work involving changes in synoptic patterns throughout the late Quaternary has involved exploring the role of shifts in the Inter-Tropical Convergence Zone (ITCZ) on the SRZ, based on diatom records at Lake Sibaya (Figure 1; Stager et al., 2013), and from the Wonderkrater (Figure 1) pollen record (Truc et al., 2013). The importance of easterly wave strength over northwestern South Africa and Namibia_, and associated ocean upwelling during drought periods, has also been explored for the WRZ, based on pollen, microcharcoal and stable carbon and nitrogen isotope records extracted from a hyrax midden at Swartruggens Mountains in the Cederberg of the Western Cape (Chase et al., 2015a). The results demonstrate that Holocene fluctuations in the easterly waves are associated with variability in summer rainfall (Chase et al., 2015a). Debates on changes in the strength of synoptic features are important to climate modellers, and many of the specifics remain unresolved for southern Africa, and indeed much of the Southern Hemisphere (Fletcher \& Moreno, 2012). While recent efforts to resolve these issues have involved the meta analysis of 13 pollen sequences spanning the SRZ (Chevalier \& Chase, 2015), the spatial distribution of records remains sparse for objective assessments attempting to determine seasonality shifts (Figure 2). Climate model developments would thus benefit from the continued collection of high temporalresolution palaeo-records across transects covering the WRZ, YRZ and SRZ (Chase and Meadows 2007). 
The distribution of sites for which palaeoenvironmental evidence of shifts in the latitudinal extent of the

Westerlies have been derived is largely clustered in the southwestern Cape and the central eastern region of South Africa, with scattered records in northern South Africa and on the west coast of Namibia (Figure 2). Sites from which reanalyses of original data have been performed and provide evidence of shifts in the Westerlies are more evenly distributed across South Africa (Figure 2). The combination of these records provides a relatively well distributed transect of sites from the winter rainfall zone in the southwestern tip of the country, to the summer rainfall zone in the northern region. This southwest to north east transect however is currently too spatially coarse for the detection of smaller amplitude fluctuations in the extent of the Westerlies, which are likely to have occurred during the Holocene. For such a transect to be strengthened, a greater number of sites throughout the Western Cape and Free State Provinces of South Africa would be necessary so as to improve the spatial resolution of reconstructions of the Westerly belt influence throughout the late Quaternary. Moreover, as much of the initial debate concerning the extent of the Westerlies involved their transgression into Namibia (Van Zinderen Bakker, 1976,1983), a greater distribution of sites in both inland and coastal Namibia would be ideal.

\section{Comparing Late Quaternary Climate Shifts in the Northern and Southern Hemispheres}

There is ongoing debate concerning the extent to which Northern Hemisphere climate events have contemporaneous Southern Hemisphere equivalents (Holmgren et al., 2003; Scott et al., 2012; Truc et al., 2013). Improvements in high resolution dating provide the capacity to resolve such uncertainties, but raise further discussion surrounding regional variations in the strength of inter-hemispheric similarities within southern African climatic histories (Tyson \& Lindesay, 1992; Holmgren et al., 2003). Climate events which have been verified for the Northern Hemisphere, but which remain unconfirmed for southern Africa, include the African Humid Period (Burrough \& Thomas, 2013) - a few-thousand year interval of particularly high moisture levels -, and short-lived cold relapses periods -including the Younger Dryas (Peteet, 1995; Thackeray \& Scott, 2006; Loftus et al., 2015), the '8.2 kyr' event (Smith et al., 2002; Fitchett et al., 2016), and the Little Ice Age (LIA) (Tyson et al., 2000). There is no conclusive published evidence for distinct, temporally synchronous ' 4.1 kyr' or '2.8 kyr' cold events (Mayewski et al., 2004; Wanner et al., 2015) in southern Africa. Unresolved 
questions include whether such events occurred in southern Africa, the timing of these events, with the potential for a lag effect having occurred, and the specific environmental conditions which may have been associated with them.

The most notable debate has focussed on the existence of a Younger Dryas cool period interrupting the warming period following the LGM, from 13,000-11,500 cal. yr BP (Abell \& Plug, 2000). Analysing pollen records from a range of sites within the interior of South Africa, Scott et al. (1995) reported that should the Younger Dryas event have occurred in southern Africa, the effects are likely to have been too minimal to induce any notable vegetation changes, and has thus not been reflected in the pollen record. However, records for a Younger Dryas cold event are identified in: a) oxygen isotope and aragonite-calcite ratios from molluscs at Elands Bay, indicating colder sea temperatures (Cohen et al., 1992); b) dinoflagellate cysts from the Cunene River Mouth indicating depressed sea surface temperatures (Dupont et al., 2004); c) oxygen isotopes from giant land snails at Bushmans' Rock Shelter indicating colder air temperatures (Abell \& Plug, 2000); d) stable carbon and nitrogen isotopes and pollen from hyrax middens from the Cederberg similarly indicating lower temperatures for the WRZ (Quick et al., 2011) and e) stable isotopes from organic matter and tooth enamel in archaeological material from Sehonghong in eastern Lesotho (Loftus et al., 2015). Notably, both Dupont et al. (2004) and Quick et al. (2011) remarked on distinct isotope signals for a Younger Dryas event, but no-the pollen signal-from the same sample in both instances reflected no anomalies, suggesting that vegetation may have remained relatively stable throughout this period. While speleothems hold the potential for higher resolution climate reconstructions, stalagmites analysed from Cold Air Cave (Figure 1) had a depositional hiatus covering this period, although it was argued that this might reflect drier conditions associated with the event (Holmgren et al., 2003). A re-evaluation of the Wonderkrater pollen record (Thackeray, 1994; Thackeray and Scott, 2006) found three samples close in age to the Northern Hemisphere Younger Dryas, during which a cold reversal was notable (Truc et al., 2013). Multivariate analysis on this reanalysed pollen record quantified the temperature incursion to $6 \pm 2^{\circ} \mathrm{C}$ (Truc et al., 2013). More recently, a Younger Dryas signal suggesting associated wet conditions has been identified in the Sudwala Cave (Figure 1) speleothem isotope record (Green et al., 2015). In contrast, a multi-proxy analysis of a sediment core from Braamhoek Wetland, $\sim 450 \mathrm{~km}$ southwest of the Sudwala caves, indicates a Younger Dryas cold period paired with dry conditions (Norström et al., 2014). Thus, increasing evidence supports the existence of a Younger 
178

179 180

Dryas event in southern Africa, but the climatic conditions during this event remain uncertain. The event is likely to have been regionally varied, sa-and therefore requires better temporally and spatially resolved studies to better capture such variations (Chase et al., 2011). The spatial distribution of sites for which proxy evidence indicates a Younger Dryas cooling period is sufficiently diverse across southern Africa (Figure 3) to suggest that such a cooling period did occur and was regional in nature. However, the absence of evidence from sites along the warm, moist east coast of southern Africa is notable. While this may be due to a coincidental absence of samples for this time period at each of the east coast sites (Figure 1), it may reflect a more interesting microclimatic effect whereby global scale cooling is obscured by persistent local warming driven by the warm Indialhas current. Deliberate investigation of samples from these sites for evidence of Younger Dryas cooling would thus be of particular value.

The subsequent cold conditions associated with the $8.2 \mathrm{kyr}$ event (driven by a meltwater pulse in the northern Atlantic (Wanner et al., 2015)) have been detected in fewer southern African records. To date, much of the evidence for this event stems from Lesotho, with isotope records from archaeological material in western Lesotho (Smith et al., 2002) demonstrating a cool period between 8,400-8,000 cal. yr BP. Cool conditions during this period have also been reconstructed from hyrax middens in the Cederberg (Chase et al., 2015b). Due to the paucity of sites for which $8.2 \mathrm{kyr}$ cooling has been detected (Figure 3), it is not yet clear whether these records indicate a teleconnection of the cold conditions in the northern Hemisphere or an independent microclimatic regional cooling event. Perhaps this cool period is apparent in so few records due to the shortlived nature of the event and the relatively poor temporal resolution of many southern African palaeoclimate chronologies. Both the $8.2 \mathrm{kyr}$ event and the Younger Dryas cooling are detected for Lesotho (Figure 3), where the higher altitude induces comparatively colder conditions than for much of southern Africa. To further understand the dynamics of this event in southern Africa, deliberate efforts to detect cool conditions during this period at a broader range of sites are imperative. Deliberate investigation for evidence of these cool events on both the warm, moist east coast and then warm, dry west coast of southern Africa would facilitate an improved understanding of the global teleconnections associated with these cooling events.

A more recently emerging debate concerns the existence of the African Humid Period in southern Africa. This event has been recorded for East Africa, occurring in the early Holocene, within the period $\sim 14,800-5,500$ cal. 
yr BP (Chase et al., 2009; Burrough \& Thomas, 2013). Evidence is presented from hyrax middens in Namibia,

208

209

210

211

212

213

214

215 suggesting the existence of an early Holocene moist period, from which it was inferred that the African Humid Period extended at least as far south as $23^{\circ}$ in Namibia (Chase et al., 2009). The extensive aridity in the Kalahari during this period poses contradictory evidence (Huntsman-Mapila et al., 2006; Nash et al., 2006), and whilst lake high-stands for Makgadikgadi) in central Botswana are dated to this period, arguably fed by a water supply from distant northerly sources (Burrough \& Thomas, 2013). Further evidence for the African Humid Period in southern Africa has been reported from stable nitrogen isotope data from hyrax middens at Austerlitz in northwestern Namibia (Chase et al., 2010). Although not referred to specifically as the African Humid Period, and with varying time periods throughout the early Holocene, reference has been made to humid periods following the postglacial warming, with evidence from peat development throughout southern Africa (Meadows, 1988), the Caledon River charcoals (Esterhuysen \& Mitchell, 1996; Esterhuysen et al., 1999), and pollen across the South African interior (Van Zinderen Bakker \& Coetzee, 1988; Scott, 1993; Lewis, 2005). This evidence is of interest, as all other reports of African Humid Period conditions are from the northern region of southern Africa (Figure 3). Comparative humidity, and the delineation of a distinct humid period is difficult, particularly for a region separated by summer and winter rainfall conditions, and with a distinct eastwest decline in precipitation (Chase \& Meadows, 2007). Deliberate exploration for evidence of African Humid Period conditions in proxy records from sites across southern Africa may provide valuable information on the southerly extent of this event. In particular, reanalysis of palaeoenvironmental data from the WRZ and YRZ would confirm the southerly extent of the influence of this climatic event, while subsequent transects spanning the known north-south and east-west manifestations of this event would enable the extent of influence to be quantified.

Where evidence for periods of abrupt climatic variability have not yet been well constrained for the mid-to late-Holocene and Pleistocene, there exists considerable evidence for the LIA cold period (AD 1300-1800) (cf. Talma et al., 1974; Herbert, 1987; Talma \& Vogel, 1992; Tyson \& Lindesay, 1992; Brook et al., 1999; Holmgren et al., 2003; Sundqvist et al., 2013; Zinke et al., 2014) in southern Africa. The majority of evidence for the LIA is based on stable isotopes from high temporal resolution speleothems (cf. Talma \& Vogel, 1992; Brook et al., 1999; Holmgren et al., 1999, 2001, 2003; Repinski et al., 1999; Tyson et al., 2000; Lee-Thorp et al., 2001; Sundqvist et al., 2013). While the existence of a LIA event has been confirmed across much of the region, the 
associated climatic conditions remain unclear. Evidence suggests that broadly dry conditions occurred during

the Little Ice Age in the SRZ (Lee-Thorpe et al., 2001; Holmgren et al., 1999; Gillson \& Ekblom, 2009; Neumann et al., 2010; Ekblom et al., 2012) and wet conditions in the WRZ (Stager et al., 2012; Weldeab et al., 2013), thus supporting Tyson and Lindesay's (1992) original hypothesis. Suggestions of a $1^{\circ} \mathrm{C}$ negative temperature departure anomaly during the Little Ice Age and $3^{\circ} \mathrm{C}$ positive departure anomaly during the preceding Medieval Warm Period (Tyson et al., 2000) remain unconfirmed against evidence of more severe cooling, as this event reflects the most pronounced $\delta^{18} \mathrm{O}$ deviation within the 25,000 yr Cold Air Cave record (Holmgren et al., 2003). An increasing number of scientific outputs detailing high resolution palaeoenvironmental reconstructions for relatively short periods spanning a few hundred to 1,000 years (cf. Brook et al., 1999; Holmgren et al., 2009; Gillson \& Ekblom, 2009; Walther \& Neumann, 2011; Ekblom et al., 2012) provides considerable potential for the identification of climatic anomalies coincident with the LIA and Medieval Warm

Period. Moreover, such studies facilitate an improved reconstruction of the relative temperature changes and associated precipitation dynamics associated which these events, to corroborate the modelled spatial variability (Barrable et al, 1998).

250

\section{The Last Glacial Maximum: Temperatures, Moisture and Glaciation}

The pronounced Last Glacial Maximum in the Northern Hemisphere is also a major climate event in southern Africa, for which there is much palaeoenvironmental evidence (Chase \& Meadows, 2007). However, debates persist on the exact timing and duration of the LGM in southern Africa, especially the timing of the coldest conditions, moisture distribution, and evidence for glaciation at high altitude locations during this period.

Studies have defined the LGM as centred around 21,000-18,000 cal. yr BP (Meadows \& Linder, 1993; Meadows \& Sugden, 1993; Partridge et al., 1997), or broadly in the range of 21,000-17,000 cal. yr BP (Partridge et al., 1999). The reported timing is also inconsistent between studies, including 20,000-16,000 cal. yr BP (Deacon \& Lancaster, 1988) and 21,000-17,000 cal. yr BP (Partridge et al., 1993). Chase and Meadows (2007) suggest that for ease of comparison, both within southern African records, and in comparison with records from elsewhere, 262 the 'Land, Oceans, Glaciers Programme' (EPILOG) definition be used, which conservatively places the LGM within the range of $24,000-18,000$ cal. yr BP (Chase \& Meadows, 2007). The timing of the coldest period during 
the LGM also remains unresolved, but pollen from Elim in the Free State (Scott, 1999) and speleothem isotope records from Cold Air Cave (Holmgren et al., 2003) indicate coldest conditions between 18,000-17,000 cal. yr BP. A statistical re-analysis of 27 pollen records spanning the Namib Desert, Namaqualand, Western Cape ecozones in southern Africa suggests that there may have been two distinct cold periods during the LGM; at $\sim 24,000$ cal. yr BP and $\sim 17,000$ cal. yr BP (Scott et al., 2012). Given that dates for the LGM in southern Africa span such a long period, it remains uncertain whether this event is contemporaneous with the Northern Hemisphere LGM, or whether some lag period exists.

Many southern African palaeoenvironmental studies report cooler temperatures during the LGM, but are unable to quantify, or do not report, the temperature depression relative to contemporary conditions (cf. Scott, 1982a; Shi et al., 1998; Scott \& Vogel, 2000; Neumann et al., 2014; Norström et al., 2014). One of the earliest studies quantifying LGM temperature depressions is based on the Wonderkrater pollen record, with results suggesting a $5-6^{\circ} \mathrm{C}$ departure from present for the Highveld interior (Scott, 1982a). A review and synthetic reconstruction of climatic conditions during the LGM (Partridge, 1999) similarly suggests an overall temperature decrease of $5^{\circ} \mathrm{C}$ throughout the LGM in southern Africa between latitudes of $24^{\circ}-33^{\circ} \mathrm{S}$. This collated reconstruction was based primarily on records from Talma \& Vogel (1992) for a $6^{\circ} \mathrm{C}$ departure, Heaton et al. (1986) for a $5.2^{\circ} \mathrm{C}$ departure, and Stute \& Talma (1997) for a $5.3^{\circ} \mathrm{C}$ departure. A much greater LGM temperature departure of $7-8^{\circ} \mathrm{C}$ is suggested based on palaeogeomorphological evidence from high altitude sites in the Western Cape Mountains (Boelhouwers \& Meiklejohn, 2002). The suggestion of an even more extreme temperature depression of $10^{\circ} \mathrm{C}$ is based on possible glacial moraines in the Eastern Cape Drakensberg (Lewis \& Illinger, 2001). More accurately resolved isotope analysis from the Cold Air Cave speleothem suggests a temperature increase of $5.7^{\circ} \mathrm{C}$ from the terminal Pleistocene to Holocene (Holmgren et al., 2003). A more recent statistical reanalysis of the improved pollen records for Wonderkrater (Thackeray \& Scott, 2007) confirms such lower estimates, reporting a temperature depression of $6 \pm 2{ }^{\circ} \mathrm{C}$ during the LGM. The extremely cold LGM temperatures implied from the palaeogeomorphological evidence may be due to misconceptions on moisture levels during the LGM, highlighting the importance of understanding both temperature and precipitation changes (Mills et al., 2012). 
293 If the temperature during the LGM was to have been $\sim 6^{\circ} \mathrm{C}$ cooler, wetter conditions would need to have

occurred in the eastern Lesotho Highlands to have produced the glacial features observed on south-facing slopes, which is attributed to a shift in the Westerlies (Rojas et al., 2009; Mills et al., 2012). The broad understanding of moisture conditions during the LGM, however, was of drier conditions in the SRZ but wetter in the WRZ (Partridge, 1999). The dry LGM in the SRZ is supported by records spanning much of South Africa (Figure 4) including Mfabeni Peatlands in Kwa-Zulu-Natal (Finch \& Hill, 2008; Baker et al., 2014), Tswaing Crater in the interior (Metcalfe, 1993; Partridge et al., 1993), together with numerous other inland sites including Wonderkrater, Rietvlei, Tate Vondo, Elim, Equus Cave, Boomplaas ( Scott 1989), and Braamhoek Wetland (Norström et al., 2009). Offshore pollen records obtained from the Cunene River Mouth suggest that southwestern Africa was also dry during the LGM (Shi et al., 1998). Records from the southern region of the country, originally argued to be homogenously wetter during the LGM, highlight local variations in moisture levels during this period (Barrable et al., 1998; Chase \& Meadows, 2007; Stowe \& Sealy, 2016). The first distinction is between the YRZ and WRZ, which were previously considered to have experienced similar climatic changes throughout much of the late Quaternary, but for which it has been found that conditions during the LGM were drier in the YRZ but wetter in the WRZ (Figure 4; Carr et al. 2006; Chase \& Meadows, 2007; Stowe \& Sealy, 2016). Further variation exists within the WRZ, with models integrating palaeoenvironmental proxy data indicating that the western coastal zone was cool and moist, whilst the southern region was colder and drier (Barrable et al. 1998; Thackeray \& Fitchett, 2016). Considerable temporal variations during the LGM may have existed, as the Cederberg isotope records suggest a dry late LGM period (Chase et al. 2011). Proxy evidence for moisture conditions during the LGM from a greater number of sites spanning the transition between the WRZ and SRZ would facilitate the determination of spatial limits to the region previously characterised by wet conditions. An increased network of sites and an improved understanding of the moisture conditions during the LGM would also contribute towards the goals of better classifying the synoptic drivers of environmental changes during the late Quaternary such as shifts in the Westerlies.

Given the considerable temperature depression of at least $5^{\circ} \mathrm{C}$ during the LGM in southern Africa, questions of possible alpine glaciation have been the subject of much debate (cf. Sparrow, 1967; Harper, 1969, Marker \& Whittington, 1971; Marker, 1991; Grab, 1996a,b, 1999, 2000, 2002a,b; Grab \& Hall, 1996; Boelhouwers \& 
Meiklejohn, 2002; Sumner, 2004; Mills et al., 2009a). Glacial moraines been positively identified on the basis of

diagnostic micro- and macro-sedimentological characteristics in eastern Lesotho; their age determinations confirm origination during the LGM (Mills et al., 2009a,b, 2012). Such glaciation was, however, spatially constrained to a few isolated high altitude south-facing sites (Mills et al., 2009a,b, 2012). More widespread glaciation in eastern Lesotho and elsewhere in southern Africa during the LGM was most unlikely (Boelhouwers \& Meiklejohn, 2002; Mills et al, 2009b). An improved constraint of the temperatures during the LGM has facilitated more accurate reconstruction of moisture conditions during this period, which suggest a northward shift in the Westerlies and an associated increase in moisture (Mills et al., 2012

A study from off-shore Namibia reports increases in wind flux during the LGM (Shi et al., 1998), but little further information on the climate dynamics for this period exists. Future work to improve reconstructions for the LGM includes refining the chronology of the LGM event, and better constraining the associated climatic fluctuations during the period (Chase \& Meadows, 2007; Chase et al., 2011). Research to quantify the climatic conditions during the LGM relative to the contemporary state, and to understand the regional variations in LGM climates and their drivers, also warrants attention (Barrable et al., 1998).

\section{FUTURE PROSPECTS OF QUATERNARY SCIENCE IN SOUTHERN AFRICA: THE IMPORTANCE OF APPLICATION}

Southern African regional palaeoenvironmental reconstructions remain relatively limited in quantity, and are spatially clustered in the more moist areas and those with alternative archive such as hyrax middens and speleothems. Consequently, large regions of the subcontinent are currently omitted, owing to numerous factors including the comparatively late inception of the discipline in the region, difficulties in obtaining suitable archives in arid regions, and limitations in skills and expertise (Neumann et al., 2008; Meadows, 2014). The uneven distribution of study sites, and the resultant omission of key bioregions (Neumann \& Bamford, 2015), requires a deliberate strategic approach in planning forthcoming palaeoenvironmental research. Increasingly, it has been suggested that the delineation of transects across southern Africa spanning these biogeographical regions would be a valuable approach to rapidly obtain sufficient data to clarify many of these debates (Chase \& Meadows, 2007). This requires the identification of key bioregions, the establishment of existing palaeoenvironmental reconstructions within these transects, and the determination of the most 
promising study sites in the excluded regions (Meadows, 2015; Neumann \& Bamford, 2015). These sites are

351

arguably those for which evidence to resolve key debates presently is absent, but where an improved spatial or temporal resolution could facilitate a direct comparison of environmental or climatic conditions for the time period in question, as have been outlined for each of the key debates.

Adapted from Scott et al. (2012, p. 101), limitations in southern African palaeoenvironmental research can be summarised as: 1) a scarcity of appropriate sites with well preserved, representative proxies; 2) the use of poor dating techniques, and/or low temporal resolution; 3) sub-regional ecological differences, many of which are unaccounted for in the palaeoenvironmental literature; 4) varied levels of, and often inadequate, taxonomic resolution in fossil identification; 5) non-uniform methods of presentation of palaeoenvironmental evidence; and 6) non-uniform methods for the interpretation of proxy-based results. The future of late Quaternary research in southern Africa necessarily needs to address these challenges in a holistic manner (Scott et al., 2012; Meadows, 2014). There has, however, been a shift in academic focus since the inception of palaeoenvironmental work in the 1960s, with climate change interpretations-reconstructions increasingly taking greatest importancedominating the discipline, replacing earlier debates regarding proxy preparation methods, the publication of fossil flora, and descriptive works on the environmental landscapes (Meadows, 2007). Much of the immediate future of palaeoenvironmental work thus arguably involves the application of an understanding of palaeoenvironments to contemporary management, including global-climate modelling, ecological monitoring through determining critical thresholds, a grasp on the role of fire, and the attribution of human influence to environmental changes (Willis et al., 2005; Meadows, 2012; Seddon et al., 2014; Gillson, 2015). The potential to address these challenges and to improve the capacity for the application of palaeoenvironmental research is improved through the adoption of multi-proxy approaches, and this relies on the successful analysis of a range of proxies (Meadows, 2012; Fitchett et al., 2016).

\section{Southern African Palaeoenvironmental Proxies}

Despite the rapid development of palaeoenvironmental science in southern Africa over recent decades, pollen remains the most commonly used proxy for late Quaternary palaeoenvironmental reconstructions in the region (Figure 5; Chase \& Meadows, 2007; Scott et al., 2012). Increasing use of isotopes, geochemistry and 
diatoms is apparent during recent decades (Figure 5). In particular, since the early 1990s, there has been a predominant use of speleothems as a palaeoenvironmental archive, from which high resolution isotope analysis is possible, supported by temporally well constrained chronologies (cf. Holmgren et al., 1995, 1999, 2001, 2003; Brook et al., 1999; Repinski et al., 1999; Finch et al., 2001; Lee-Thorp et al., 2001; Sundqvist et al., 2013; Green et al., 2015). Isotopes are also increasingly used from a range of archives including sediment cores, hyrax middens, and shells and bones at archaeological sites (Cohen et al., 1992; Cohen \& Tyson, 1995; Johnson et al., 1997; Abell \& Plug, 2000; Chase et al., 2012; Weldeab et al., 2013; Meadows, 2014). The increasing diversity of palaeoenvironmental proxies being used across published work and at particular field sites, highlights the benefits that the region has been afforded by enhanced funding allocation and international collaboration (Chase \& Meadows, 2007; Meadows, 2007; Fitchett et al., 2016). This enables a wider range of palaeoenvironmental variables, tipping points, and stressors to be analysed, and facilitates multi-proxy work (Meadows, 2014). The few studies which have utilised foraminifera (Strachan et al., 2014, 2015 2016), phytoliths (Rossouw et al., 2009; Burrough et al., 2012; Backwell et al., 2014), dinoflagellate cysts (Dupont et al., 2004) and biomarkers (Norström et al., 2014; Carr et al., 2015), would suggest that there is a greater wealth of suitable palaeoenvironmental proxies available in southern Africa than has typically been applied to Quaternary science in the region. Important to the improved use of multiple proxies is a robust understanding of the limitations of the proxy and its archive (Meadows, 2014). Recent analysis of the variability of the distribution of pollen within offshore marine sediments from the west coast of South Africa highlight the importance in understanding the provenance of the proxy material sampled (Zhao et al., 2016)

\section{Application in Climate Modelling}

A valuable application of southern African palaeoenvironmental data is to validate climate models. The first southern African climate model to include both surface and upper air dynamics for the contemporary climate was compared with, albeit sparse, palaeoclimatic reconstructions for the region (Cockroft et al., 1987). From the correlation between model simulations and palaeoclimatic evidence, support was provided for the conceptual palaeoclimatic model proposed by Tyson (1986). At a smaller geographical scale, and with a greater volume of palaeoclimatic work for comparison, Barrable et al. (1998) evaluated the palaeoclimatic evidence for the southern African WRZ against climate model simulations, and confirmed a difference in moisture conditions within the WRZ during the LGM. It was argued that such correlations between models and proxy 
data have the potential to improve both methods, as proxy data can validate the climate model output and provide further data to improve the reliability of projections, whilst the model data can improve explanations of the synoptic drivers of palaeoclimatic changes, and indicate locations for which palaeoclimatic studies

\section{Applications in Conservation Management Decisions}

A further important application of palaeoenvironmental work is to improve our understanding of ecosystem functions by exploring the dynamics of their changes over variable and long time-periods, although the adoption of palaeoenvironmental evidence by ecologists has arguably been overdue (Willis et al., 2005; Meadows, 2012; Seddon et al., 2014; Fitchett et al., 2017). The value of understanding the long-term history of ecological systems is most apparent with regard to the management of grasslands, as decisions inherently require the nature of grassland development to be understood, because anthropogenic development through deforestation would have significantly different implications to the existence of grasslands in the region prior to permanent human occupation (Meadows \& Linder, 1993; Scott, 2002; Gillson, 2015). Management decisions which relied on the assumption that grasslands were anthropogenically initiated, have been critiqued by palaeoenvironmental evidence from pollen, phytoliths and stable isotopes of southern African grasslands (Scott, 2002), presence of Afromontane grasslands prior to permanent human occupation in southern Africa (Meadows \& Linder, 1993), and a progressive shift from $C_{4}$ dominated grasslands and open savannah to $C_{3}$ thicket, forest and densely wooded savannah in KwaZulu-Natal (Gillson, 2015). Studies of the ecological histories in other biomes include an analysis of the palaeoenvironmental history of the Cape Floristic Kingdom (Meadows \& Sugden, 1993), and ofthe Podocarpus forest history in Maputuland (Finch \& Hill, 2008), and the classification of Chrysocoma ciliata as an invasive in the Lesotho Highlands (Fitchett et al., 2017). It can further be argued that studies which do not intend to provide purely historical information from 
palaeoenvironmental proxies, would be of great value to ecologists for determining historical vegetation

communities, and drivers causing their spatial shifts (Willis et al. 2005; Meadows, 2012; Fitchett et al., 2017).

437

438 Of increasing interest within the grassland history of southern Africa is the role of fire, and the relationships

439 between fire intensity and vegetation composition (Duffin, 2008; Ekblom \& Gillson, 2010). An empirical

440 relationship between charcoal deposits in surface sediment samples from Kruger National Park (Figure 1) and

441 the proximity of fires, area of fires and fire intensity, has been developed (Duffin et al., 2008). This has enabled

442 the comparison of palaeoenvironmental records, which indicate higher fire intensity related to higher

443 percentages of herbaceous cover and lower percentages of woody plant growth (Duffin, 2008). Further work in

444 the Kruger National Park has challenged the assumption that fire suppresses tree seedling growth and hence

445 encourages grasslands. During grassland-dominated periods, the high frequency of fire appears to shift the

446 system to a savannah environment by increasing woody recruitment, while during savanna-dominated periods

447 fire limits woody recruitment and retains the environment in a savanna state (Ekblom \& Gillson, 2010). A

448 longer-spanning record covering the mid- to late-Holocene for Graskop and Versailles in Mpumalanga

449 Province, South Africa (Figure 1), indicates that fire was rare during the grassland dominated period prior to

4504,000 cal. yr BP, but that fire incidence increases from 600 cal. yr BP following a decrease in Podocarpus pollen,

451 and spiked in the last 70 years due to human influence (Breman et al., 2011). At the scale of interglacial-glacial

452 cycles, a study of charcoal from a core off the coast of Namibia found six periods of heightened fire incidence

453 over the past 170,000 cal. yr, which coincided with precessional forcing of north-south shifts in the ITCZ and

454 notably occurred during periods with wetter and cooler climates, assumed to be due to changes in rainfall

455 seasonality (Daniau et al., 2012). A more complete understanding of the dynamics between vegetation and fire

456 throughout periods of vegetation change enables improved ecosystem fire management, and these

457 developments in palaeoecological fire studies provide an example illustrating the value of

458 palaeoenvironmental work to ecologists (Ekblom \& Gillson, 2010).

459

460 Determining Anthropogenic Influence

461 The third application of palaeoenvironmental work to contemporary management is in determining the

462 influence of prolonged anthropogenic settlement on the natural environment (Baxter \& Meadows, 1999;

463 Seddon et al., 2014). This has been facilitated through improvements in sampling resolution and dating 
accuracy to capture high resolution environmental changes over the past few centuries (Baxter \& Meadows, 1999; Neumann et al., 2008; Reinwarth et al., 2013; Neumann et al., 2014). This is particularly important in regions with a high level of human occupation, as progressively the anthropogenic effect on vegetation

\section{CONCLUSION}

Late Quaternary palaeoenvironmental science, and the reconstruction of late Quaternary climates and environments, has rapidly advanced over the past half century in southern Africa. This has provided a baseline understanding of the rate and cyclicity of past climate changes, and a broad understanding of palaeoclimatic and palaeoenvironmental boundaries across the region. However, this research has arguably unearthed more questions than have been answered. The complex contemporary climate dynamics and biome divisions in southern Africa extend back through the Holocene and Pleistocene, resulting in an intricate relationship 
between climate, space and time. Debates that remain unresolved include the spatial extent of the WRZ and the role of the westerlies throughout the late Quaternary, the comparability of Northern and Southern Hemisphere palaeoclimatic events, and the climatic conditions of the LGM. To continue to resolve these 495 debates, high resolution palaeoclimatic and palaeoenvironmental reconstructions are required from a larger

range of sites covering existing geographical gaps, and a concerted effort to integrate the findings of palaeoclimatic reconstructions into regional and global climate models.. A key limitation has been the difficulties in obtaining archives from the more arid regions of southern Africa, yet recent work on hyrax

499

middens is rapidly addressing this concern. With climatic influences from the ITCZ and the Westerlies, and with forcings from the regional oceans, moisture sources off the cold Atlantic and warm Indian Oceans, southern 501

Africa provides a biogeographically rich backdrop to explore environmental shifts related to both small- and large-amplitude climatic shifts.

\section{3}

504

\section{REFERENCES}

ABELL, P.I. \& PLUG, I. 2000 The Pleistocene/ Holocene transition in South Africa: evidence for the Younger Dryas event. Global Planetary Change 26: 173-179.

BACKWELL, L.R., MCCARTHY, T.S., WADLEY, L., HENDERSON, Z., STEININGER, C.M., DE KLERK, B., BARRÉ, M., LAMOTHE, M., CHASE, B.M., WOODBORNE, S., SUSINO, G.J., BAMFORD, M.K., SIEVERS, C., BRINK, J.S., ROSSOUW, L., POLLAROLO, L., TROWER, G., SCOTT, L. \& D'ERRICO, F. 2013. Multiproxy record of late Quaternary climate change and Middle Stone Age Human occupation at Wonderkrater, South Africa. Quaternary Science Reviews 99: 42-59.

BAKER, A., ROUTH, J., BLAAUW, M. \& ROYCHOUDHURY, A.N. 2014. Geochemical records of palaeoenvironmental controls on peat forming processes in the Mfabeni peatland, Kwazulu Natal, South Africa since the Late Pleistocene. Palaeogeography, Palaeoclimatology and Palaeoecology 395: 95-106.

BAMFORD, M.K., NEUMANN, F.H. \& SCOTT, L. 2016. Pollen, charcoal and plant macrofossil evidence of Neogene and Quaternary environments in southern Africa. In: Knight, J. and Grab, S.W. (Eds.) Quaternary environmental change in southern Africa: physical and human dimensions. Cambridge: Cambridge University Press. 
BARRABLE, A., MEADOWS, M.E. \& HEWITSON, B.C. 1998. Environmental reconstruction and climate modelling of the Late Quaternary in the winter rainfall region of the Western Cape, South Africa. South African Journal of Science 98: 611-616.

BAXTER, A. \& MEADOWS, M. 1999. Evidence for Holocene sea level changes at Verlorenvlei, Western Cape, South Africa. Quaternary International 56: 65-79.

BOELHOUWERS, J.C. \& MEIKLEJOHN, K.I. 2002. Quaternary periglacial and glacial geomorphology of Southern Africa: review and synthesis. South African Journal of Science 98: 47-55.

BREMAN, E., GILLSON, L. \& WILLIS, K. 2011. How fire and climate shaped grass-dominated vegetation and forest mosaics in northern South Africa during past millennia. The Holocene 22(12): 1427-1439.

BROOK, G.A., RAFTER, M.A., RAILSBACK, L.B., SHEEN, S.W. \& LUNDBERG, J. 1999. A high-resolution proxy record of rainfall and ENSO since AD 1550 from layering in stalagmites from Anjohibe Cave, Madagascar. The Holocene 9(6): 695-705.

BURROUGH, S.L., BREMAN, E. \& DODD, C. 2012. Can phytoliths provide and insight into past vegetation of the Middle Kalahari paleolakes during the late Quaternary? Journal of Arid Environments 82: 113-116.

BURROUGH, S.L. \& THOMAS, D.S.G. 2013. Central southern Africa at the time of the African Humid Period: a new analysis of Holocene palaeoenvironmental and palaeoclimate data. Quaternary Science Reviews 80: $29-46$.

CARR, A.S., THOMAS, D.S.G., BATEMAN, M.D., MEADOWS, M.E. \& CHASE, B. 2006. Late Quaternary palaeoenvironments of the winter-rainfall zone of southern Africa: Palynological and sedimentological evidence from the Agulhas Plain. Palaeogeography, Palaeoclimatology and Palaeoecology 239: 147-165.

CARR, A.S., BATEMAN, M.D., ROBERTS, D.L., MURRAY-WALLACE, C.V., JACOBS, Z. \& HOLMES, P.J. 2010. The last interglacial sea-level high stand on the southern Cape coastline of South Africa. Quaternary Research 73: 351-363. 
CARR, A.S., BOOM, A., CHASE, B.M., MEADOWS, M.E. \& GRIMES, H.L. 2015. Holocene sea level and environmental change on the west coast of South Africa: evidence from plant biomarkers, stable isotopes and pollen. Journal of Palaeolimnology 53: 415-432.

CHASE, B.M. \& MEADOWS, M.E. 2007. Late Quaternary dynamics of southern Africa's winter rainfall zone. Earth Science Reviews 84: 103-138.

CHASE, B.M., MEADOWS, M.E., SCOTT, L., THOMAS, D.S.G., MARAIS, E., SEALY, J. \& REIMER, P.J. 2009. A record of rapid Holocene climate change preserved in hyrax middens from southwestern Africa. Geology 37: 703 706.

CHASE, B.M., MEADOWS, M.E., CARR, A.S. \& REIMER, P.J. 2010. Evidence for progressive Holocene aridification in southern Africa recorded in Namibian hyrax middens: Implications for African Monsoon dynamics and the "African Humid Period". Quaternary Research 74(1): 36-45.

CHASE, B.M., QUICK, L.J., MEADOWS, M.E., SCOTT, L., THOMAS, D.S.G. \& REIMER, P.J. 2011. Late glacial interhemispheric climate dynamics revealed in South African hyrax middens. Geology 39(1): 19-22.

CHASE, B.M., SCOTT, L., MEADOWS, M.E., GIL-ROMERA, G., BOOM, A., CARR, A.S., REIMER, P.J., TRUC, L., VALSECCHI, V. \& QUICK, L.J. 2012. Rock hyrax middens: A palaeoenvironmental archive for southern African drylands. Quaternary Science Reviews 56: 107-125.

CHASE, B.M., LIM, S., CHEVALIER, M., BOOM, A., CARR, A.S., MEADOWS, M.E. \& REIMER, P.J. 2015a. Influence of tropical easterlies in southern Africa's winter rainfall zone during the Holocene. Quaternary Science Reviews 107: 138-148.

CHASE, B.M., BOOM, A., CARR, A.S., CARRÉ, M., CHEVALIER, M., MEADOWS, M.E., PEDRO, J.B., STAGER, J.C. \& REIMER, P.J. 2015b. Evolving southwest African response to abrupt deglacial North Atlantic climate change events. Quaternary Science Reviews 121: 132-136.

CHEVALIER, M. \& CHASE, B.M. 2015. Southeast African records reveal a coherent shift from high- to lowlatitude forcing mechanisms along the east African margin across last glacial-interglacia transition. Quaternary Science Reviews 125: 117-130. 
CHRISTENSEN, J.H. \& HEWITSON, B. 2007. Regional Climate Projections. Climate Change 2007: The Physical Science Basis. Contribution of Working Group I to the Fourth Assessment Report of the Intergovernmental Panel on Climate Change. Cambridge University Press: Cambridge.

COCKROFT, M.J., WILKINSON, M.J. \& TYSON, P.D. 1987. The application of a present-day climatic model to the Late Quaternary in southern Africa. Climatic Change 10: 161-181.

COETZEE, J.A. 1967. Pollen analytical studies in East and Southern Africa. Palaeoecology of Africa 3: 1-146.

COHEN, A.L., PARKINGTON, J.E., BRUNDRIT, G.B. \& VAN DER MERWE, N.J. 1992. A Holocene marine climate record in mollusc shells from the southwest African coast. Quaternary Research 38: 379-385.

COHEN, A.L. \& TYSON, P.D. 1995. Sea-surface temperature fluctuations during the Holocene off the south coast of Africa: implications for terrestrial climate and rainfall. The Holocene 5(3): 304-312

DANIAU, A.L., GOÑI, M.F.S., MARTINEZ, P., URREGO, D.H., BOUT-ROUMAZEILLES, V., DESPRAT, S. \& MARLON, J.R. 2012. Orbital-scale climate forcing of grassland burning in southern Africa. PNAS 110(13): 5069-5073.

DEACON, J. \& LANCASTER, I.N. 1988. Late Quaternary Palaeoenvironments of Southern Africa. Oxford: Clarendon Press.

DUFFIN, K.I. 2008. The representation of rainfall and fire intensity in fossil pollen and charcoal records from a South African savannah. Review of Palaeobotany and Palynology 151: 59-71.

DUFFIN, K.I., GILLSON, L. \& WILLIS, K.J. 2008. Testing the sensitivity of charcoal as an indicator of fire events in savanna environments: quantitative predictions of fire proximity, area and intensity. Holocene 18: 279291.

DUPONT, L.M., KIM, J.H., SCHNEIDER, R.R. \& SHI, N. 2004. Southwest African climate independent of Atlantic sea surface temperatures during the Younger Dryas. Quaternary Research 61: 318-324

EKBLOM, A. \& GILLSON, L. 2010. Fire history and fire ecology of Northern Kruger (KNP) and Limpopo National Park (PNL), southern Africa. The Holocene 20(7): 1063-1077. 
EKBLOM, A., GILLSON, L., RISBERG, J., HOLMGREN, K. \& CHIDOUB, Z. 2012. Rainfall variability and vegetation dynamics of the lower Limpopo Valley, Southern Africa, 500 AD to present. Palaeogeography, Palaeoclimatology, Palaeoecology 363-364: 69-78.

ENGELBRECHT, F.A., MCGREGOR, J.L. \& ENGELBRECHT, C.J. 2009. Dynamics of the conformal-cubic atmospheric model projected climate-change signal over southern Africa. International Journal of Climatology 29: 1013-1033.

ENGELBRECHT, C.J., LANDMAN, W.A., ENGELBRECHT, F.A. \& MALHERBE, J. 2015. A synoptic decomposition of rainfall over the Cape south coast of South Africa. Climate Dynamics 44: 2589-2607.

ESTERHUYSEN, A. \& MITCHELL, P. 1996. Palaeoenvironmental and archaeological implications of charcoal assemblages from Holocene sites in western Lesotho, Southern Africa. Palaeoecology of Africa 24: 203232.

ESTERHUYSEN, A.B., MITCHELL, P.J. \& THACKERAY, J.F. 1999. Climatic change across the Pleistocene/Holocene boundary in the Caledon River southern Africa: Results of a factor analysis of charcoal assemblages. Southern African Field Archaeology 8: 28-34.

FINCH, A.A., SHAW, P.A., WEEDON, G.P. \& HOLMGREN, K. 2001. Trace element variation in speleothem aragonite: potential for palaeoenvironmental reconstruction. Earth and Planetary Science Letters 186: 255-267.

FINCH, J.M. \& HILL, T.R. 2008. A late Quaternary pollen sequence from Mfabeni Peatland, South Africa: Reconstructing forest history in Maputaland. Quaternary Research 70: 442-460.

FINNÉ, M., NORSTRÖM, E., RISBERG, J. \& SCOTT, L. 2010. Siliceous microfossils as late-Quaternary paleoenvironmental indicators at Braamhoek wetlands, South Africa. The Holocene 20(5): 747-760.

FITCHETT, J.M., KNIGHT, J. \& GRAB, S.W. 2016. Minerogenic microfossil records of Quaternary environmental change in southern Africa. In: Knight, J. \& Grab, S.W. (Eds.) Quaternary environmental change in southern Africa: physical and human dimensions. Cambridge: Cambridge University Press. 
614

615

616

617

618

619

620

621

622

623

624

625

626

627

628

629

630

631

632

633

634

635

636

637

FITCHETT, J.M., MACKAY, A.W., GRAB, S.W. \& BAMFORD, M.K. 2016. Holocene climatic variability indicated by a multi-proxy record from southern Africa's highest wetland. The Holocene, DOI: $\underline{10.1177 / 0959683616670467 .}$

FITCHETT, J.M. \& BAMFORD, M.K. 2017. The validity of the Asteraceae: Poaceae fossil pollen ratio in discrimination of the southern African summer- and winter-rainfall zones. Quaternary Science Reviews, 160: 85-95.

FITCHETT, J.M., BAMFORD, M.K., MACKAY, A.W. \& GRAB, S.W. 2017. Chrysocoma ciliata L. (Asteraceae) in the Lesotho Highlands: An anthropogenically introduced invasive or a niche coloniser? Biological Invasions, In Press.

FLETCHER, M.S. \& MORENO, P.I. 2012. Have the Southern Westerlies changed in a zonally symmetric manner over the last 14,000 years? A hemisphere-wide take on a controversial problem. Quaternary International 253: $32-46$.

GILLSON, L. \& EKBLOM, A. 2009. Untangling anthropogenic and climatic influence on riverine forest in the Kruger National Park, South Africa. Vegetation History Archaeobotany 18: 171-185.

GILLSON, L. 2015. Evidence of a tipping point in a southern African savanna? Ecological complexity 21: 78-86.

GORDON, N., GARCÍA-RODRIGUEZ, F. \& ADAMS, J.B. 2012. Palaeolimnology of a coastal lake on the Southern Cape coast of South Africa: Sediment geochemistry and diatom distribution. Journal of African Earth Sciences 75: 14-24.

GRAB, S. \& HALL, K. 1996. North-facing hollows in the Lesotho/Drakensberg mountains: hypothetical palaeoenvironmental reconstructions? South African Journal of Science 92: 183-184.

GRAB, S.W. 1996a. A note on the morphology of miniature sorted stripes at Mafadi Summit, High Drakensberg. South African Geographical Journal 78(2): 59-63.

GRAB, S. 1996b. Debris deposits in the high Drakensberg, South Africa: Possible indicators for plateau, niche and cirque glaciation. Geomorphology 103: 389-403. 
638

639

640

641

642

643

644

645

646

647

648

649

650

651

652

653

654

655

656

657

658

659

GRAB, S. 1999. Block and debris deposits in the High Drakensberg, Lesotho, southern Africa: Implications for high altitude slope processes. Geografiska Annaler 81(1): 1-16.

GRAB, S. 2000. Stone-banked lobes and environmental implications, High Drakensberg, Southern Africa. Permafrost and Periglacial Processes 11: 177-187.

GRAB, S. 2002a. Characteristics and palaeoenvironmental significance of relict sorted patterned ground, Drakensberg plateau, southern Africa. Quaternary Science Reviews 21: 1729-1744.

GRAB, S. 2002b. A note on needle-ice mound formation in the High Drakensberg, southern Africa. Permafrost and Periglacial Processes 13: 315-318.

GREEN, H., PICKERING, R., DRYSDALE, R., JOHNSON, B.C., HELLSTROM, J. \& WALLACE, M. 2015. Evidence for global teleconnections in a late Pleistocene speleothem record of water balance and vegetation change at Sudwala Cave, South Africa. Quaternary Science Reviews 110: 114-130.

HARPER, G. 1969. Periglacial evidence in South Africa during the Pleistocene epoch. Palaeoecology of Africa 4: 71-91.

HEATON, T.H.E., TALMA, A.S. \& VOGEL, J.C. 1986. Dissolved gas palaeotemperatures and 180 variations derived from groundwater near Uitenhage, South Africa. Quaternary Research 25: 79-88.

HENDEY, Q.B. \& VOLMAN, T.P. 1986. Last Interglacial sea levels and coastal caves in the Cape Province, South Africa. Quaternary International 25: 189-198.

HERBERT, R.S. 1987. Late Holocene climatic change: the Little Ice Age and El Niño from planktonic foraminifera in sediments off Walvis Bay, South West Africa. Bulletin No. 18, Marine Geosciences Unit, Department of Geology, University of Cape Town. UCT: Cape Town.

HOLMGREN, K., KARLÉN, W. \& SHAW, P.A. 1995. Paleoclimatic significance of the stable isotopic composition and petrology of a Late Pleistocene stalagmite from Botswana. Quaternary Research 43: 320-328. 
660

661

662

663

664

665

666

667

668

669

670

671

672

673

674

675

676

677

678

679

680

681

682

holmgren, K., KARLÉN, W., LAURITZeN, S.E., LEE-THORP, J.A., PARTRIDGE, T.C., PIKETH, S., REPINSKI, P., STEVENSON, C., SVANERED, O. \& TYSON, P.D. 1999. A 3000-year high-resolution stalagmite-based record of palaeoclimate for northeastern South Africa. The Holocene 9(3): 295-309.

HOLMGREN, K., TYSON, P.D., MOBERG, A. \& SVANERED, O. 2001. A preliminary 3000-year regional temperature reconstruction for South Africa. South African Journal of Science 97: 49-51.

HOLMGREN, K., LEE-THORP, J.A., COOPER, G.R.J., LUNDBLAD, K., PARTRIDGE, T.C., SCOTT, L., SITHALDEEN, R., TALMA, A.S. \& TYSON, P.D. 2003. Persistent millennial-scale climatic variability over the past 25,000 years in Southern Africa. Quaternary Science Reviews 22: 2311-2326.

HUNTSMAN-MAPILA, P., RINGROSE, S., MACKAY, A.W., DOWNEY, W.S., MODISI, M., COETZEE, S.H., TIERCELIN, J.J., KAMPUNZU, A.B. \& VANDERPOST, C. 2006. Use of the geochemical and biological sedimentary record in establishing palaeo-environments and climate change in the Lake Ngami basin, NW Botswana. Quaternary International 148: 51-68.

JOHNSON, B.J., MILLER, G.H., FOGEL, M.L. \& BEAUMONT, P.B. 1997. The determination of the late Quaternary palaeoenvironments at Equus Cave, South Africa, using stable isotopes and amino acid racemization in ostrich eggshell. Palaeogeography, Palaeoclimatology, Palaeoecology 136: 121-137.

KRISTEN, I., FUHRMANN, A., THORPE, J., RÖHL, U., WILKES, H. \& OBERHÄNSLI, H. 2007. Hydrological changes in southern Africa over the last $200 \mathrm{Ka}$ as recorded in lake sediments from the Tswaing impact crater. South African Journal of Geology 110: 311-326.

LEE-THORP, J.A., HOLMGREN, K., LAURITZEN, S.E., LINGE, H., MOBERG, A., PARTRIDGE, T.C., STEVENSON, C. \& TYSON, P.D. 2001. Rapid climate shifts in the southern African interior throughout the mid to late Holocene. Geophysical Research Letters 28(23): 4507-4510.

LEWIS, C.A. 2005. Late Glacial and Holocene palaeoclimatology of the Drakensberg of the Eastern Cape, South Africa. Quaternary International 129: 33-48. 
683 LEWIS, C.A. \& ILLINGER, P.M. 2001. Late Quaternary glaciation in southern Africa: moraine ridges and glacial 684 deposits at Mount Enterprise in the Drakensberg of the Eastern Cape Province, South Africa. Journal of 685 Quaternary Science 16(4): 365-374.

686

Livingstone, D. 1975. Late Quaternary climatic change in Africa. Annual Review of Ecology and Systematics 6: $249-280$

688

LOFTUS, E., STEWART, B.A., DEWAR, G. \& LEE-THORP, J. 2015. Stable isotope evidence of MIS 3 to middle 689

MAUD, R.R. 1968. Quaternary geomorphology and soil formation in coastal Natal. Seitschrift fur Geomorphologie 7: 155-199. 
MAYEWESKI, P.A., ROHLING, E.E., STAGER, J.C., KARLÉN, W., MAASCH, K.A., MEEKER, L.D., MEYERSON, E.A., GASSE, F., VAN KREVELD, S., HOLMGREN, K., LEE-THORP, J., ROSQVIST, G., RACK, F., STAUBWASSER, M., SCHNEIDER, R.R. \& STEIG, E.J. 2004. Holocene climate variability. Quaternary Research 62(3): 243-255.

MEADOWS, M.E. \& BAXTER, A.J. 2001. Holocene vegetation history and palaeoenvironments at Klaarfontein Springs, Western Cape, South Africa. The Holocene 11(6): 699-706.

MEADOWS, M.E. 1988. Late Quaternary Peat Accumulation in Southern Africa. CATENA 15: 459-472.

MEADOWS, M.E. 2007. Classics in physical geography revisited. Coetzee, J.A.1967: Pollen analytical studies in East and Southern Africa. Palaeoecology of Africa 3, 1-146. Progress in Physical Geography 31(3): 313-317.

MEADOWS, M.E. 2012. Quaternary environments: Going forwards, looking backwards? Progress in Physical Geography 35(4): 539-547.

MEADOWS, M.E. 2014. Recent methodological advances in Quaternary palaeoecological proxies. Progress in Physical Geography 38(6): 807-817.

MEADOWS, M.E. 2015. Seven decades of Quaternary palynological studies in southern Africa: a historical perspective. Transactions of the Royal Society of South Africa 70(2): 103-108.

MEADOWS, M.E. \& LINDER, H.P. 1993. A palaeoecological perspective on the origin of Afromontane grasslands. Journal of Biogeography 20(4): 345-355.

MEADOWS, M.E. \& SUGDEN, J.M. 1993. The late Quaternary palaeoecology of a floristic kingdom: the southwestern Cape South Africa. Palaeogeography, Palaeoclimatology, Palaeoecology 101: 271-281.

MEADOWS, M.E., BAXTER, A.J. \& PARKINGTON, J. 1996. Late Holocene environments at Verlorenvlei, Western Cape Province, South Africa. Quaternary International 33: 81-95.

METCALFE, S. 1993. Evolution of the Pretoria Saltpan - a diatom record spanning a full glacial-interglacial cycle. Hydrobiologia 269: 159-166.

MILLS, S.C., GRAB, S.W. \& CARR, S.J. 2009a. Recognition and palaeoclimatic implications of late Quaternary niche glaciation in eastern Lesotho. Journal of Quaternary Science 24(7): 647-663. 
MILLS, S.C., GRAB, S.W. \& CARR, S.J. 2009b. Late Quaternary moraines along the Sekhokong Range, eastern Lesotho: Contrasting the geomorphic history of north- and south-facing slopes. Geografiska Annaler 91(2): $121-140$

MILLS, S., GRAB, S.W., REA, B., CARR, S. \& FARROW, A. 2012. Shifting westerlies and precipitation patterns during the Late Pleistocene in southern Africa determined using glacier reconstruction and mass balance modelling. Quaternary Science Reviews 55: 145-159.

NASH, D.J., MEADOWS, M.E. \& GULLIVER, V.L. 2006. Holocene environmental change in the Okavango Panhandle, northwest Botswana. Quaternary Science Reviews 25: 1302-1322.

NEUMANN, F.H., STAGER, J.C., SCOTT, L., VENTER, H.J.T. \& WEYHENMEYER, C. 2008. Holocene vegetation and climate records from Lake Sibaya, KwaZulu-Natal (South Africa). Review of Palaebotany and Palynology 152: $113-128$.

NEUMANN, F.H., SCOTT, L., BOUSMAN, C.B. \& VAN, A.S.L. 2010. A Holocene sequence of vegetation change at Lake Eteza, coastal KwaZulu-Natal, South Africa. Review of Palaeobotany and Palynology 162: 39-53.

NEUMANN, F.H., SCOTT, L. \& BAMFORD, M.K. 2011. Climate change and human disturbance of fynbos during the late Holocene at Princess Vlei, Western Cape, South Africa. The Holocene 21(7): 1137-1149.

NEUMANN, F.H., BOTHA, G.A. \& SCOTT, L. 2014. 18,000 years of grassland evolution in the summer rainfall region of South Africa: evidence from Mahwaqa Mountain, KwaZulu-Natal. Vegetation History and Archaeobotany 23(6): 665-681.

NEUMANN, F.H. \& BAMFORD, M.K. 2015, Shaping of modern southern African biomes: Neogene vegetation and climate changes. Transactions of the Royal Society of South Africa. DOI: 10.1080/0035919X.2015.1072859.

NORSTRÖM, E., SCOTT, L., PARTRIDGE, T., RISBERG, J. \& HOLMGREN, K. 2009. Reconstruction of environmental and climate changes at Braamhoek wetland, eastern escarpment South Africa, during the last 16000 years with emphasis on the Pleistocene-Holocene transition. Palaeogeography, Palaeoclimatology, Palaeoecology 271(3): 240-258. 
754

755

756

757

758

759

760

761

762

763

764

765

766

767

768

769

770

771

772

773

774

775

776

777

NORSTRÖM, E., NEUMANN, F.H., SCOTT, L., SMITTENBERG, R.H., HOLMSTRAND, H., LUNDQVIST, S., SNOWBALL, I., SUNDQVIST, H.S., RISBERG, J. \& BAMFORD, M. 2014. Late Quaternary vegetation dynamics and hydro-climate in the Drakensberg, South Africa. Quaternary Science Reviews 105: 48-65.

PARTRIDGE, T.C. 1999. Tswaing: Investigations into the Origin, Age and Palaeoenvironments of the Pretoria Saltpan. Council for Geosciences: Pretoria.

PARTRIDGE, T.C., KERR, S.J., METCALFE, S.E., SCOTT, L., TALMA, A.S. \& VOGEL, J.C. 1993. The Pretoria Saltpan: a 200,000 year Southern African lacustrine sequence. Palaeogeography, Palaeoclimatology, Palaeoecology 101: 317-337.

PARTRIDGE, T.C., DE MENOCAL, P.D., LORENTZ, S.A., PAIKER, M.J. \& VOGEL, J.C. 1997. Orbital forcing of climate over South Africa: A 200,000-year rainfall record from the Pretoria Saltpan. Quaternary Science Reviews 16: $1125-1135$.

PARTRIDGE, T.C., SCOTT, L. \& HAMILTON, J.E. 1999. Synthetic reconstructions of southern African environments during the Last Glacial Maximum (21-18 kyr) and the Holocene Altithermal (8-6 kyr). Quaternary International 57/58: 207-214.

PETEET, D. 1995. Global Younger Dryas. Quaternary International 28: 93-104.

QUICK, L.J., CHASE, B.M., MEADOWS, M.E., SCOTT, L. \& REIMER, P.J. 2011. A 19.5 kyr vegetation history from the central Cederberg Mountains, South Africa: Palynological evidence from rock hyrax middens. Palaeogeography, Palaeoclimatology, Palaeoecology 309: 253-270.

QUICK, L.J., CARR, A.S., MEADOWS, M.E., BOOM, A., BATEMAN, M.D., ROBERTS, D.L., REIMER, P.J. \& CHASE, B.M. 2015. A late Pleistocene-Holocene multi-proxy record of palaeoenvironmental change from Still Bay, southern Cape Coast, South Africa.

QUICK, L.J., MEADOWS, M.E., BATEMAN, M.D., KIRSTEN, K.L., MÄUSBACHER, R., HABERZETTL, T. \& CHASE, B.M. 2016. Vegetation and climate dynamics during the last glacial period in the fynbos-afrotemperate forest ecotone, southern Cape, South Africa. Quaternary International 404: 136-149. 
778

779

780

781

782

783

784

785

786

787

788

789

790

791

792

793

794

795

796

797

798

799

800

801

802

RAMSAY, P.J. 1995. 9000 years of sea-level change along the southern African coastline. Quaternary International 31: 71-75.

RAMSAY, P.J. \& COOPER, J.A.G. 2002. Late Quaternary Sea-Level Change in South Africa. Quaternary Research 57: 82-90.

REINWARTH, B., FRANZ, S., BAADE, J., HABERZETTI, T., KASPER, T., DAUT, G., HELMSCHROT, J., KIRSTEN, K.L., QUICK, L.J., MEADOWS, M.E. \& MÄUSBACHER, R. 2012. A 700-year record on the effects of climate and human impact on the southern Cape coast inferred from lake sediments of Eilandvlai, Wilderness Embayment, South Africa. Geografiska Annaler 95(4): 345-360.

REPINSKI, P., HOLMGREN, K., LAURITZEN, S.E. \& LEE-THORP, J.A. 1999. A late Holocene climate record from a stalagmite, Cold Air Cave, Northern Province, South Africa. Palaeogeography, Palaeoclimatology, Palaeoecology 150: 269-277.

ROJAS, M., MORENO, P.I., KAGEYAMA, M., CRUCIFIX, M., HEWITT, C., ABE-OUCHI, A., OHGAITO, R., BRADY, E.C. \& HOPE, P. 2009. The Southern westerlies during the last glacial maximum in PMIP2 simulations. Climate Dynamics 32: 525-548

ROSSOUW, L., STYNDER, D.D. \& HAARHOF, P. 2009. Evidence for opal phytolith preservation in the Langebaan 'E' Quarry Varswater Formation and its potential for palaeohabitat reconstruction. South African Journal of Science 105: 223-227.

SCHALKE, H.J.W.G. 1973. The Upper Quaternary of the Cape Flats area (Cape Province, South Africa). Scripta Geologica 15: 1-48.

.SCOTT, L. 1976. Preliminary palynological results from the Alexandersfontein Basin near Kimberley. Annuals of the South African Museum 71: 73-189.

SCOTT, L. 1982a. A Late Quaternary pollen record from the Transvaal Bushveld, South Africa. Quaternary International 17: 339-370.

SCOTT, L. 1982b. Late Quaternary fossil pollen grains from the Transvaal, South Africa. Review of Palaeobotany and Palynology 36: 241-278. 
SCOTT, L. 1989. Climatic conditions in southern Africa since the Last Glacial Maximum, inferred from pollen analysis. Palaeogeography, Palaeoclimatology, Palaeoecology 70: 345-353.

SCOTT, L. 1993. Palynological evidence for late Quaternary warming episodes in Southern Africa. 806 Palaeogeography, Palaeoclimatology, Palaeoecology 101: 229-235.

SCOTT, L. 1999. Vegetation history and climate in the Savanna biome South Africa since 190,000 ka: a comparison of pollen data from the Tswaing Crater (the Pretoria Saltpan) and Wonderkrater. Quaternary International 57/58: 215-223.

SCOTT, L. 2002. Grassland development under glacial and interglacial conditions in southern Africa: a review of pollen, phytolith and isotope evidence. Palaeogeography, Palaeoclimatology, Palaeoecology 177: 47-57.

SCOTT, L., STEENKAMP, M. \& BEAUMONT, P.B. 1995. Palaeoenvironmental conditions in South Africa at the Pleistocene-Holocene transition. Quaternary Science Reviews 14: 937-947.

SCOTT, L. \& VOGEL, J.C. 2000. Evidence for environmental conditions during the last 20000 years in Southern Africa from ${ }^{13} \mathrm{C}$ in fossil hyrax dung. Global and Planetary Change 26: 207-215

SCOTT, L., NEUMANN, F.H., BROOK, G.A., BOUSAN, C.B., NORSTRÖM, E. \& METWALLY, A.A. 2012. Terrestrial fossil-pollen evidence of climate change during the last 26 thousand years in Southern Africa. Quaternary Science Reviews 32: 100-118.

SEDDON, A.W., MACKAY, A.W., BAKER, A.G., BIRKS, H.J.B., BREMAN, E., BUCK, C.E., ELLIS, E.C., FROYD, C.A., GILL, J.L., GILLSON, L., JOHNSON, E.A., JONES, V.J., JUGGINS, S., MACIAS-FAURIA, M., MILLS, K., MORRIS, J.L., NOGUÉS-BRAVO, D., PUNYASENA, S.W., ROLAND, T.P., TANENTZAP, A.J., WILLIS, K.J., ABERHAN, M., VAN ASPEREN, E.N., AUSTIN, W.E.N., BATTARBEE, R.W., BHAGWAT, S., BELANGER, C.L., BENNETT, K.D., BIRKS, H.H., BRONK RAMSAY, C., BROOKS, S.J., DE BRUYN, M., BUTLER, P.G., CHAMBERS, F.M., CLARKE, S.J., DAVIES, A.L., DEARING, J.A., EZARD, T.H.G., FEURDEN, A. FLOWER, R.J., GELL, P., HAUSMANN, S., HOGAN, E.J., HOPKINS, M.J., JEFFERS, E.S., KORHOLA, A.A., MARCHANT, R., KIEFER, T., LAMENTOWICZ, M., LAROCQUE-TOBLER, I., LÓPEZ-MERINO, L., LIOW, L.H., MCGOWAN, S., MILLER, J.H., MONTOYA, E., MORTON, O., NOGUÉ, S., ONOUFRIOU, C., BOUSCH, L.P., RODRIGUEZ-SANCHEZ, F., ROSE, N.L., SAYER, C.D., SHAW, H.E., PAYNE, R., SIMPSON, G., SOHAR, K., WHITEHOUSE, N.J., WILLIAMS, J.W. \& WITKOWSKI, 
A. 2014. Looking forward through the past: identification of 50 priority research questions in palaeoecology. Journal of Ecology 102: 256-267.

SHI. N., DUPONT, L.M., BEUG, H.J. \& SCHNEIDER, R. 1998. Vegetation and climate changes during the last 21000 years in S.W. Africa based on a marine pollen record. Vegetation History and Archaeobotany 7: 127-140.

SMITH, J.M., LEE-THORPE, J.A. \& SEALY, J.C. 2002. Stable carbon and oxygen isotopic evidence for late Pleistocene to middle Holocene climatic fluctuations in the interior of southern Africa. Journal of Quaternary Science 17(7): 683-695.

SPARROW, G.W.A. 1967. Pleistocene periglacial topography in southern Africa. Journal of Glaciology 6(46): 551-559.

STAGER, J.C., MAYEWSKI, P.A., WHITE, J., CHASE, B.M., NEUMANN, F.H., MEADOWS, M.E., KING, C.D. \& DIXON, D.A. 2012. Precipitation variability in the winter rainfall zone of South Africa during the last $1400 \mathrm{yr}$ linked to the austral westerlies. Climate of the Past 8: 877-887.

STAGER, J.C., RYVES, D.B., KING, C., MADSON, J., HAZZARD, M., NEUMANN, F.H. \& MAUD, R. 2013. Late Holocene precipitation variability in the summer rainfall region of South Africa. Quaternary Science Reviews 67: 105-120.

STOWE, M-J. \& SEALY, J. 2016. Terminal Pleistocene and Holocene dynamics of southern Africa's winter rainfall zone based on carbon and oxygen isotope analysis of bovid tooth enamel from Elands Bay Cave. Quaternary International 404: 57-67.

STRACHAN, K.L., FINCH, J.M., HILL, T. \& BARNETT, R.L. 2014. A late Holocene sea-level curve for the east coast of South Africa. South African Journal of Science 110 (1/2): 1-9

STRACHAN, K.L., HILL, T.R., FINCH, J.M. \& BARNETT, R.L. 2015. Vertical zonation of foraminifera assemblages in Galpins Marsh, South Africa. Journal of Foraminiferal Research 45(1): 29-41. 
STRACHAN, K.L., FINCH, J.M., HILL, T.R., BARNETT, R.L., MORRIS, C.D. \& FRENZEL, P. 2016. Environmental controls on the distribution of salt-march foraminifera from the southern coastline of South Africa. Journal of Biogeography 43: 887-898.

STUTE, M. \& TALMA, A.S. 1997. Isotope techniques in the study of past and current environmental changes in the hydrosphere and the atmosphere. IAEA Vienna Symposium 1997, Isotopic techniques in the study of environmental change. International Atomic Energy Agency: Vienna, pp. 307-318.

SUMNER, P.D. 2004. Geomorphic and climate implications of relict openwork block accumulations near Thabana-Ntlenyaya, Lesotho. Geografiska Annaler 86(3):289-302.

SUNDQVIST, H.S., HOLMGREN, K., FOHLMEISTER, J., ZHANG, Q., BAR MATTHEWS, M., SPÖTL, C. \& KÖMICH, H. 2013. Evidence of a large cooling between 1690 and 1740 AD in southern Africa. Scientific Reports 3: 1767.

TALMA, A.S., VOGEL, J.C. \& PARTRIDGE, T.C. 1974. Isotopic contents of some Transvaal speleothems and their palaeoclimatic significance. South African Journal of Science 70: 135-140.

TALMA, A.S. \& VOGEL, J.C. 1992. Late Quaternary palaeotemperatures derived from a speleothem from Cango Caves, Cape Province, South Africa. Quaternary Research 37: 203-213.

THACKERAY, J.F. 1994 Comment on temperature indices from a late Quaternary terrestrial sequence at Wonderkrater, South Africa. Quaternary Research 42:354-355.

THACKERAY, J.F. \& SCOTT, L. 2006. The Younger Dryas in the Wonderkrater sequence, South Africa? Annals of the Transvaal Museum 43: 111-112.

THACKERAY, J.F. \& FITCHETT, J.M. (2016). Rainfall seasonality captured in micromammalian fauna late quaternary contexts, South Africa. Palaeontologia Africana 51. In Press.

TRUC, L., CHEVALIER, M., FAVIER, C., CHEDDADI, R., MEADOWS, M.E., SCOTT, L., CARR, A.S., SMITH, G.F. \& CHASE, B.M. 2013. Quantification of climate change for the last 20,000 years from Wonderkrater, South Africa: Implications for the long-term dynamics of the Intertropical Convergence Zone. Palaeogeography, Palaeoclimatology, Palaeoecology 386: 575-587. 
876

877

878

879

880

881

882

883

884

885

886

887

888

889

890

891

892

893

894

895

896

897

898

899

TYSON, P.D. 1986. Climatic change and variability in southern Africa. Cape Town: Oxford University Press.

TYSON, P.D. \& LINDESAY, J.A. 1992. The climate of the last 2000 years in southern Africa. The Holocene 2: $271-$ 278.

TYSON, P.D., KARLÉN, W., HOLMGREN, K. \& HEISS, G.A. 2000. The Little Ice Age and medieval warming in South Africa. South African Journal of Science 96: 121-126.

VAN ZINDEREN BAKKER, E.M. \& COETZEE, J.A. 1988. A review of Late Quaternary pollen studies in east, central and southern Africa. Review of Palaeobotany and Palynology 55: 155-174.

VAN ZINDEREN BAKKER, E.M. 1955. A Preliminary Survey of the Peat Bogs of the Alpine Belt of Northern Basotholand. Acta Geographica 14: 413-422

VAN ZINDEREN BAKKER, E.M. 1976. The evolution of late Quaternary paleoclimates of Southern Africa. Palaeoecology of Africa 9: 160-202.

VAN ZINDEREN BAKKER, E.M. 1983. A Lateglacial and post-glacial pollen record from the Namib Desert. Palaeoecology of Africa 16: 421-428.

WALTHER, S.C. \& NEUMANN, F.H. 2011. Sedimentology, isotopes and palynology of late Holocene cores from Lake Sibaya and the Kosi Bay system (KwaZulu-Natal, South Africa). South African Geographical Journal 9(2): 133-153.

WANNER, H., MERCOLLI, L., GROSJEAN, M. \& RITZ, S.P. 2015. Holocene climate variability and change; a databased review. Journal of the Geological Society 172(2): 254-263.

WELDEAB, S., STUUT, J.B.W., SCHNEIDER, R.R. \& SIEBEL, W. 2013. Holocene climate variability in the winter rainfall zone of South Africa. Climate of the Past 9: 2347-2364.

WILLIS, K.J., GILLSON, L., BMCIC, T.M. \& FIGUEROA-RANGEL, B.L. 2005. Providing baselines for biodiversity measurement. Trends in Ecology and Evolution 20(3): 107-108.

ZHAO, X., DUPONT, L., MEADOWS, M.E. \& WEFER, G. 2016 Pollen distribution in the marine surface sediments of the mudbelt along the west coast of South Africa. Quaternary International 404-44-56. 
1

2
903

904

905

906

907

908

909

910

911

912

913

914

915

916

\section{5}

ZINKE, J., LOVEDAY, B.R., REASON, C.J.C., DULLO, W.C. \& KROON, D. 2014. Madagascar corals track sea surface temperature variability in the Agulhas Current core region over the past 334 years. Scientific Reports 4: 4393-4401.

\section{List of Figures}

Figure 1: Locations of selected southern African sites at which published palaeoenvironmental reconstructions have been undertaken.

Figure 2: Location of sites for which evidence for shifts in the Westerlies has been derived from original and reanalysed palaeoenvironmental proxy records.

Figure 3: Location of sites for which evidence of the Younger Dryas, 8.2 kyr Event and the African Humid Period have been reported.

Figure 4: Sites for which moist and dry conditions respectively have been reconstructed for the LGM.

Figure 5: Number of proxies used in published palaeoenvironmental reconstructions for southern Africa: 1950-

2015. Data derived from, and cross-checked using, Google Scholar, Science Direct and Web of Knowledge. 


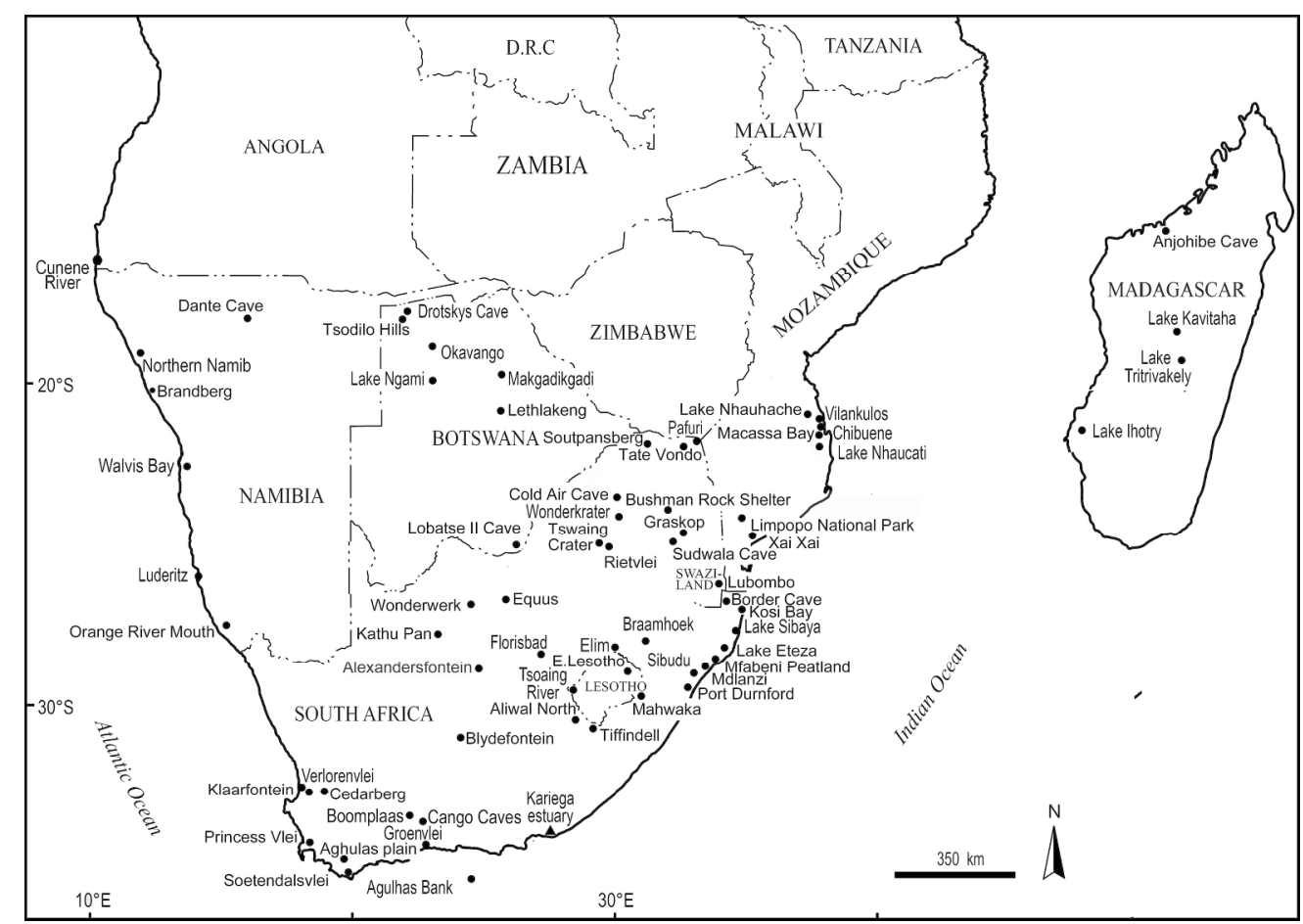

Figure 1: Locations of selected southern African sites at which published palaeoenvironmental reconstructions have been undertaken.

$118 \times 84 \mathrm{~mm}(600 \times 600 \mathrm{DPI})$ 
Figure 2: Location of sites for which evidence for shifts in the Westerlies has been derived from original and reanalysed palaeoenvironmental proxy records.

\section{$118 \times 84 \mathrm{~mm}(600 \times 600 \mathrm{DPI})$}


Figure 3: Location of sites for which evidence of the Younger Dryas, 8.2 kyr Event and the African Humid Period have been reported.

$118 \times 84 \mathrm{~mm}(600 \times 600 \mathrm{DPI})$ 
Figure 4: Sites for which moist and dry conditions respectively have been reconstructed for the LGM.

$$
118 \times 84 \mathrm{~mm}(600 \times 600 \mathrm{DPI})
$$




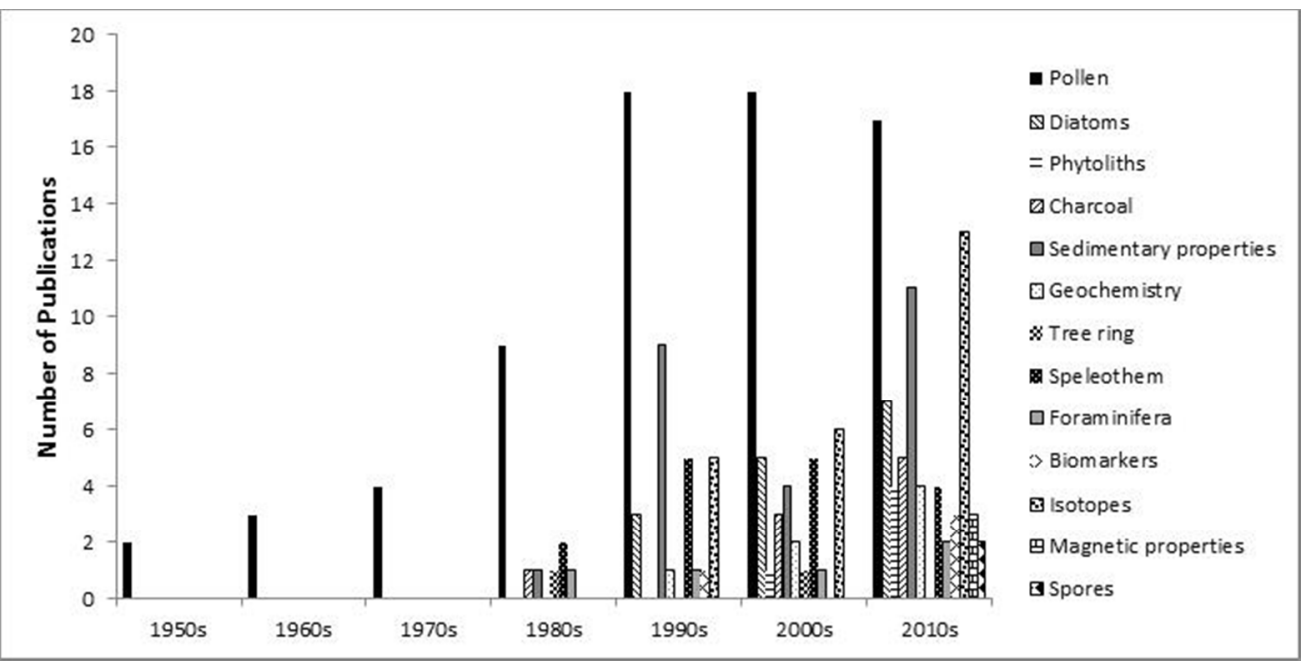

Figure 5: Number of proxies used in published palaeoenvironmental reconstructions for southern Africa: 1950-2015. Data derived from, and cross-checked using, Google Scholar, Science Direct and Web of Knowledge.

$194 \times 97 \mathrm{~mm}(96 \times 96 \mathrm{DPI})$ 